\title{
ALFRED HOPE GOSSE
}

Alfred Hope Gosse, the son of a doctor, was born at Wallaroo in South Australia in 1882. After attending St. Peter's College, Adelaide, he came to England and entered Gonville and Caius College, Cambridge, where he graduated in 1907. He completed his medical course at St. Mary's Hospital, winning the Cheadle gold medal for clinical medicine, and qualified in 1910 . He was successively house physician, medical officer in the inoculation department, and medical registrar at St. Mary's, before he became research assistant to Sir James Mackenzie at the London Hospital in 1914. In that year also he was elected to the staff of the Brompton Hospital.

When war broke out he served as registrar at the Third L.G.H. (Territorial) and in 1916 volunteered for service in Mesopotamia where at first he was stationed with the 40 B.G.H. at Basra. His administrative skill caused him to be chosen as commanding officer for the Officers' Hospital, a large Arab mansion at Beit Naama on the banks of the Tigris, where he did excellent work.

On his return to England in 1919, Hope Gosse was appointed physician to outpatients at St. Mary's Hospital, where he specialized in diseases of the heart and lungs, while retaining an interest in all branches of medicine. He had a large private practice but never let this interfere in the slightest with his hospital duties which he carried out most faithfully. He was a wise and enthusiastic teacher and a good friend to the students. During the war of 1939-45 while serving in the E.M.S. he spent a large part of his time at St. Mary's, living and mingling with the students and doing a great amount of teaching. He retired from hospital eight years ago but continued private practice for a few years longer.

From 1942 he was the independent medical expert in diseases of the chest and heart to the Ministry of Pensions, where his clearly expressed and carefully reasoned opinions were highly valued. He served on the committee to consider whether amputation of a limb and the wearing of a prosthesis could in the course of time initiate or aggravate cardiovascular disorders. For more than twenty years he was medical officer to the Medical Sickness Insurance Society and took great interest in this work. His common sense and good judgement must have played an important part in building up the success of the Society. From the information he obtained in this way he wrote The Health of the Doctor dealing with the morbidity and mortality from various diseases (Brit. med. J., 1942, 2, 567). He did not agree that coronary disease was specially common in doctors and thought its high incidence in the Registrar-General's returns was largely due to more accurate diagnosis in doctors.

He was a painstaking rather than a ready writer of medical articles; he wrote and rewrote them and would alter them again and again to get the exact sense that he wished. At one time he had been editor of St. Mary's Hospital Medical School Gazette and this had made him a judge of good writing. He wrote on The Heart and its Rhythm in Acute Rheumatism with Gunson and Parkinson (Quart. J. Med., 1920, 13, 363) and on The Heart in Pulmonary Tuberculosis with Wingfield (Brit. J. Tuberc., 1937, 31, 92) and more recently with Oram the section on Embolism in the British Encyclopaedia of Medical Practice.

After retirement he gave time to interests that he had at heart. He was chairman of the distribution committee of the Hospital Sunday Fund, and interviewed many hospital almoners and took immense trouble to see that the grants should be given to objects for which the National Health Service made little or no provision.

Hope Gosse was tall and broad in proportion, and fresh-coloured. He walked with a very slight stoop at the shoulders. His face had a pleasant placid expression, sometimes a little quizzical. He shrank from public speaking but loved a private discussion. He was very fair-minded and always 
ready to listen to the other side of the question: he took long to make up his mind, but after going over every argument carefully and reaching a decision, he seldom changed it. Thus as adviser to the Ministry of Pensions he had considered very carefully whether cardiac infarction was in any way due to service conditions, and having made up his mind that the evidence was against this he was reluctant to make exceptions.

He was conscientious to a fault and almost over-scrupulous. In financial matters he was accurate and punctilious: his first care was to lay aside from his income that which would be needed for the income tax, which he always paid as soon as he received the demand note. As treasurer of the Medical Society of London he greatly improved its financial position; one particular investment he watched for twenty years until it reached a value that he had hoped for, when he sold with great advantage to the society. He had great self-control; for many years he was a heavy cigarette smoker, but came to the conclusion that he was becoming a slave to the habit and gave it up at once and for ever.

His word was his bond and there were few who could equal his reliability. He was a faithful friend and many are the men whom he helped in their hour of need. All his actions were above board and the slightest suspicion of any underhand action in others excited his disgust. Hope Gosse was modest and retiring but he was very sociable and popular. He was at different times president of the Harveian Society and the Medical Society of London. At one time he was a very good bridge player, and he loved to watch a cricket match. Though Australian born he was an impartial onlooker, and when asked which side he favoured gave the characteristic reply-" the side which is doing badly." He also enjoyed a good race-meeting at Goodwood or Ascot.

He never married and for a long time his mother lived with him in his attractive Harley Street home, surrounded by good furniture and pictures, in which he was interested. He was always fond of children and they of him and for years would not miss the Christmas festivities at his hospital where he played the part of Father Christmas to their great delight.

As a cardiologist, Hope Gosse early recognized the significance of the symptoms of his fatal disease, and characteristically put all his affairs in perfect order before going into hospital. $\mathrm{He}$ never liked to cause anyone trouble and almost his last words were those of apology to the nurses for any trouble he was causing them. By his departure his many friends have lost an influence in their lives that they can never hope to regain. 